\title{
Leadership styles and roles on instructional supervision of the school heads of area 3 division of Batangas: Basis for management program
}

Dimaculangan, Dorie $\$
Saimsim Elementary School, Philippines (doriedimaculangan@yahoo.com)

Received: 30 March 2021

Available Online: 15 July 2021
Revised: 13 May 2021 DOI: 10.5861 /ijrse.2021.672

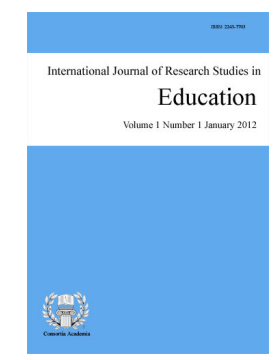

ISSN: $2243-7703$ Online ISSN: 2243-7711

OPEN ACCESS

\section{Abstract}

Instructional leadership is learning-focused, learning for both students and adults, and learning which is measured by improvement in instruction and in the quality of student learning. Instructional leadership must reside with a team of leaders of which the principal serves as the leader of leaders. Utilizing quantitative descriptive research design, the study was conducted to find out the preferred leadership styles and perceived role on instructional supervision of School Heads of selected schools from Area 3 Division of Batangas and thereby provide input to management program. Based on the foregoing findings and conclusions of the study, and in order to affect effective leadership and sound administrative competence, the researcher puts forward the following: School heads should, through planned exercises, be able to negotiate and analyze strategies and tactics for effectively implementing their available power in administration and leadership and must serve as role models. Role modeling can be an effective teaching-learning strategy, providing managers have the skills and abilities required. Further research on individual's and environment characteristics could contribute significantly to our understanding of how leadership styles and administrative competence. More research is necessary on the effects of personality and characteristics of the organizational environment.

Keywords: leadership style, supervision, instructional supervision, school head, management, organization 


\section{Leadership styles and roles on instructional supervision of the school heads of area 3 division of Batangas: Basis for management program}

\section{Introduction}

There is no good or bad leadership style. Each person has his or her preferences for leadership. Task-motivated leaders are at their best when the group performs successfully such as achieving a new sales record or outperforming the major competitor. Relationship-oriented leaders are at their best when greater customer satisfaction is gained and a positive company image is established. Organizational effectiveness is the main concern of all education institutes. Over the years there have been many different models of effectiveness along with the criteria for measuring organizational effectiveness. In addition, it became more prominent and switched to being a concept from the status of a construct (Henry, 2011). This concept is related to issues such as the ability of an organization to access and absorb resources and consequently achieve its aims (Federman, 2016).

Ashraf (2012) said that a unit that is individually ineffective in terms of cooperation with the rest of the organization is doomed to failure. Organizational effectiveness is the proficiency of the organization at having access to essential resources. However, McCann (2014) noted it as the criterion of the organization's successful fulfillment of their purposes through core strategies. Conflict in schools takes different forms; for example, teachers seem reluctant to obey the principals, they do not seem to follow rules or accept extra work, they do not easily get along with their principals. Principals adopt an authoritative approach, for example, they pressure teachers for an uninterrupted working of the school activities. It, therefore, becomes common that conflict between teachers and the school principal occur frequently at any time in the school. In institutions, conflict occurs between various individuals because of their frequent interaction with each other. The primary conflict manager in the school is the principal, the person who has the power to make changes and who is responsible for outcomes in the conflict episode. That is why the researcher aims to have an input to organizational effectiveness.

The same scenario or situation is observed by the researcher in the selected public elementary schools in the Area 3 Division of Batangas, where she is currently teaching. She would like to widen the scope of the investigation whether the same situation is true to the other school by including selected public schools' heads. Therefore, this paper would like to determine the leadership styles and administrative competence of school heads and to have an input of organizational effectiveness.

\subsection{Theoretical framework}

This study is anchored on the 4D Framework of Instructional Leadership developed by the College of Education of the University of Washington (2018). The 4D Framework describes the essence of effective instructional leadership and guides school leaders in improving teaching and learning for all students. Among school-related factors, school leadership is second only to teaching in its potential influence on student learning. Instructional leadership is a critical aspect of school leadership. The work of instructional leaders is to ensure that every student receives the highest quality instruction each day. Doing so requires that instructional leaders lead for the improvement of the quality of teaching and the improvement of student learning.

The framework is not the total of the work of instructional leaders. Rather, it is a description of the most salient aspects of instructional leadership. The concepts of the framework are based on five core beliefs. They drive our work in school leadership here at the Center for Educational Leadership. Instructional leadership is learning-focused, learning for both students and adults, and learning is measured by improvement in instruction and the quality of student learning. Instructional leadership must reside with a team of leaders of which the principal serves as the "leader of leaders." A culture of public practice and reflective practice is essential for 
effective instructional leadership and the improvement of instructional practice. Instructional leadership addresses the cultural, linguistic, socioeconomic, and learning diversity in the school community. Instructional leadership focuses upon the effective management of resources and people — recruiting, hiring, developing, evaluating particularly in changing environments.

\subsection{Conceptual framework}

The research paradigm used in this study. It shows the interrelationship among the selected variables used in this study. The major concept of this study focused on the relationship of the leadership styles and level of instructional supervision and profile of school heads in the Area 3 Division of Batangas. The intended output of the study is the development of a management program that is tailored fit to the needs of the school heads in the Area.

\subsection{Statement of the problem}

The study aims to find out the preferred leadership styles and perceived role on instructional supervision of School Heads of selected schools from the Area 3 Division of Batangas. Specifically, it will seek answers to the following questions: First, what is the profile of the School Heads in terms of age, gender, position, and the number of years as a school head. Second, what are the Leadership Styles of the School Heads? Third, what are the perceptions of the school heads on their roles on instructional supervision in terms of instructional development, curriculum development, staff development, and learners' development? Fourth, is there a significant association between the profile variables of the respondents and their leadership styles? Fifth, is there a significant association between the profile variables of the respondents and instructional supervision? Lastly, is there a relationship between leadership styles and instructional management of the School Heads?

\subsection{Hypotheses}

The following hypotheses were formulated and tested: First and foremost, there is no significant association between the profiles of the respondents and the power styles. Next, there is no significant association between the outline of the respondents and the administrative competence. Finally, there is no significant association between the power styles and managerial competence of the school heads.

\subsection{Significance of the study}

The results of the study are deemed beneficial to the following: First, is in the school administrators because, in this study, the administrator may gain a clearer insight into the kind of strategies/styles that can be used to develop conflict management strategies to the effectiveness of the organizational enhancement program. With this, they can integrate the findings of this study into their team-building program. Then the staff and faculty in this study may serve as a realization point for them on how to deal with conflict to attain an effective organizational enhancement program. This study will provide them learning on how to improve organizational effectiveness. Lastly, the future researcher who will conduct similar or related studies may utilize this reference material. The recommendations of this study will help them decide to conduct similar research in the future.

\subsection{Scope and limitations}

The study will look into the Leadership Styles and perceived roles for instructional supervision and the Profile of elementary School Heads in the Area 4 Division of Batangas. The research was conducted between November and December of the Academic Year 2019-2020. The study will involve the administrators, principals, and head teachers of the schools in the division. 


\section{Related literature and studies}

This chapter presents the conceptual and research literature which compose of ideas of writers, researchers, and educators that the researcher believed to have relevance to the current undertaking research about the challenges and practices of school principals and master teachers as instructional supervisors.

\subsection{Related literature}

Foreign School supervision, in general, has existed in all countries for many decades and occupies a pivotal position in the management of education, which can be understood as an expert technical service most importantly concerned with scientific study and improvement of the conditions that surround learning and pupil growth (Alemayehu, 2018). However, the organization and function of supervision and even its terminology are different in different countries. For example, in many developed countries, such as United Kingdom (UK), United States, and other European countries and some African countries such as Lesotho, Senegal, Tanzania, and Nigeria the terms "inspector" and "inspection" are still being used (Grauwe, 2017; Lee, Dig, \& Song, 2018).

In these countries, much more attention has been given to inspectional supervision which is carried out by external inspectors aimed at evaluating and controlling the performance of schools. Such type of external supervision is stated by Vashist (2014) as a process of leadership and development of leadership within groups, which evaluates the educational product in light of accepted educational objectives (standards), studying the teaching-learning situation to determine the antecedents of satisfactory and unsatisfactory pupil growth and achievement, and school improvement. Leadership style plays an important role in shaping the behavior and attitudes of employees in an organization. Reinke (2009) identifies four leadership styles and stresses that each style has a fundamental foundation and that most leaders practice some form of leadership or a combination of styles during their normal work routine.

Autocratic Leadership Style - Autocratic leaders limit self-determination and autonomy and push followers to accept the ideas. Such leadership decreases subordinates' sense of control and goal striving and increases powerlessness. Autocratic leaders are in complete control as they push their followers to conform to their image. They leave little room for free thought. Although not a popular approach to leadership there are situations when it is most suitable, for when an organization is in a crisis and followers require clear and concise direction.

Bureaucratic Leadership Style - Bureaucratic Leadership style is commonly defined as one that emphasizes procedures. It is the use of rules, policies, the hierarchy of authority, written documentation, standardization, and other bureaucratic mechanisms to standardize behavior and assess performance (Brian 2006). Bureaucratic leaders are motivated by the need to control through documentation. Followers are merely instruments used to create bureaucracy within the organization as well as understand the procedures they write. Bureaucratic leaders produce followers that do only what is expected and nothing more (Reinke 2009).

Democratic Leadership Style - Democratic leadership style has been called a participative style because it suggests that leaders allow followers to participate in the management process. There are times when allowing followers to participate in management decisions can cause some democratic leaders to fear losing control. Richard (2011) suggests in democratic leadership, the role of the leader is not just solving problems but more importantly is to identify the conditions for effective solutions. Democratic leaders are motivated by highly skilled and experienced employees who are not afraid to express their opinions.

In addition, according to Goldman (2012), democratic organizations typically have the following six characteristics: policies are determined by a group of organizations, technical and job performance measures are discussed so they are understood by all, leaders provide advice to members in regards to implementing tasks, members are free to choose with whom they work, the group determines the distribution of tasks, and leaders try to be objective in giving praise and criticism. Goldman (2000) states that leaders using a democratic style of leadership build consensus through participation, but these leaders also expect a higher level of excellence and 
self-direction. From my own experience, I have observed that these leaders have time to listen and share ideas with their followers. They also tend to be more flexible and are responsive to one's needs. They can motivate teachers to participate in decision-making and are respectful. The democratic style of leadership emphasizes group and leader participation in the making of policies. Decisions about organizational matters are arrived at after consultation and communication with various people in the organization. The leader attempts as much as possible to make each feel that he is an important member of the organization. Communication is multidirectional while ideas are exchanged between employees and the leader (Heenan \& Bennis, 2016).

In this style of leadership, a high degree of staff morale is always enhanced (MBA, 2014). In other words, consultation, teamwork, and participation are the common key characteristics of successful schools. House and Mitchell (as reported in Oyetunyi, 2016) suggest that a leader can behave in different ways in different situations. The following are the four kinds of leaders"e behavior.

Laissez-Faire Leadership Style - Laissez-faire leaders are those who avoid their assigned managerial duties. This includes behavior such as failing to initiate any structure for their employees, making no effort to show any consideration for their workers ' being, failing to communicate performance expectations to employees, failing to hold employees accountable, and making no effort to maintain motivation and morale (Reinke 2009). Many leaders who practice this style of leadership are inclined to allow their followers freedom to solve important issues on their own. Laissez-faire leaders surround themselves with highly skilled, experienced, and educated followers that are capable of working unsupervised. Laissez-faire leaders are satisfied with their position and need only perform well enough to keep their status in the organization.

Furthermore, laissez-Faire leadership is when leaders are hands-off and allow group members to make the decisions. With this style, freedoms are fully determined by group goals, techniques, and working methods. Leaders rarely intervene. Laissez-faire style is described by Hackman and Johnson (2009) as the most effective style, especially where followers are mature and highly motivated. Laissez-faire leadership style allows complete freedom to group decisions without the leader's participation. Thus, subordinates are free to do what they like. The role of the leader is just to supply materials. The leader does not interfere with or participate in the course of events determined by the group.

Directive leadership style - is similar to the task-oriented style. The leader who uses this type of leadership style provides teachers with specific guidelines, rules, and regulations about planning, organizing, and performing activities. This style is deemed to be appropriate when the subordinates" ability is low and or the task to be performed is complex or ambiguous. Job satisfaction is increased when the leader gives more directives (Hoy \& Miskel, 2010).

Supportive leadership style - is more of a relationship-oriented style. It requires the leader to be approachable and friendly. He/she displays concern for the well-being and personal needs of the subordinates. $\mathrm{He} / \mathrm{she}$ creates an emotionally supportive climate. This style is effective when subordinates lack self-confidence; work on dissatisfying or stressful tasks and when work does not provide job satisfaction (Hoy \& Miskel, 2010).

Participative Style - the leader who employs this style consults with subordinates for ideas and takes their ideas seriously when making decisions. This style is effective when subordinates are well motivated and competent (Lussier \& Achua, 2010). Moreover, every leader in every organization performs certain roles/tasks for the smooth running of the organization and improvement of organizational performance. As a result, Ezeuwa (2015) sees it as the act of influencing people so that they strive willingly and enthusiastically towards the accomplishment of goals. In the same manner, Ukeje (2016) observes that leadership means influencing people to work willingly with zeal towards the achievement of the corporate goals. A leader cannot work alone; he must have people to influence, direct, carry along, sensitize and mobilize towards the achievement of the corporate goal. Whether a leader emphasizes the task or human relations is usually considered central to leadership style. 


\subsection{Local}

The principal's collaboration with the master teacher (MT) in instructional supervision is yet another significant aspect of the decentralization model. Master teachers are highly experienced classroom teachers leading school efforts to improve teacher performance. They mentor new teachers and assist with teachers' performance appraisals. By working with master teachers, principals are likely to receive the necessary support in taking on their new role as instructional supervisors. Also, collaboration with Master Teachers allows principals to accurately identify teacher training areas. Master Teachers have traditionally been involved in running in-service training (INSET) activities. The larger the school, the more Master Teacher posts. In high schools, the Master Teachers work closely with Subject Head Teachers. The Master Teacher receives a salary comparable to that of the principal, however, they do not have leadership responsibilities as the principal does and are not held accountable for school performance. The design of INSET supports the Division to work in collaboration with school principals or school-based INSET coordinators (i.e. master teacher) appointed by the school principal to identify teacher training needs, design and propose workshops and sessions, manage training events, and monitor and evaluate training. Funding for implementation of proposed training is subject to a process of review and approval by the Division.

According to Pedraza (2012), organizational effectiveness can be defined as the efficiency with which an association can meet its objectives. This means an organization that produces the desired effect or an organization that is productive without waste. Organizational effectiveness is about each individual doing everything they know how to do and doing it well; in other words, organizational efficiency is the capacity of an organization to produce the desired results with a minimum expenditure of energy, time, money, and human and material resources. The desired effect will depend on the goals of the organization, which could be, for example, making a profit by producing and selling a product. An organization, if it operates efficiently, will produce a product without waste. If the organization has both organizational effectiveness and efficiency, it will achieve its goal of making a profit by producing and selling a product without waste. In economics and the business world, this may be referred to as maximizing profits.

The main measure of organizational effectiveness for a business will generally be expressed in terms of how well its net profitability compares with its target profitability. Additional measures might include growth data and the results of customer satisfaction surveys.

Highly effective organizations exhibit strengths across five areas: leadership, decision making and structure, people, work processes and systems, and culture. For an organization to achieve and sustain success, it needs to adapt to its dynamic environment. Evaluating and improving organizational effectiveness and efficiency is one strategy used to help ensure the continued growth and development of an organization. Measuring organizational effectiveness can be an inexact science since each entity will have a different list of criteria and priorities to weigh and consider through self-assessment.

However, organizational effectiveness measures the big-picture performance of a business, across a broad range of criteria. Financial performance, long-term planning, internal structure, and adherence to core values may all be critical components in understanding organizational effectiveness. To get a clear idea of an organization's effectiveness, it is important to create a clear list of criteria to assess. No two organizations will have the same list of criteria, which is why many for-profit and non-profit groups measure effectiveness through self-assessment. By working creatively to invent new business strategies for areas of ineffectiveness, workers may develop a stronger sense of loyalty, purpose, and dedication to the job.

Since organizational effectiveness is difficult to express in a concrete formula, a company may choose to state the results of an assessment through specific goals achieved or desired. Turning up areas of ineffectiveness can also be tremendously beneficial to an organization. Areas that need improvement give a company a concrete strategy for the future and allow workers, shareholders, donors, or customers to get excited about the 
improvements coming down the pipeline. Treating current weaknesses as a road map for future changes is a great way to increase effectiveness (Pedraza, 2012). A related study was conducted by Reyes (2016) to find out the "Conflict Management Leadership Styles of Private Elementary School Heads in the West District of Lipa; An Input to Organizational Effectiveness". The study employed descriptive research design the study through a survey conducted using adopted questionnaires on conflict management styles and leadership styles. It was found out that the conflict management style used by most of the respondents is Collaborating style (71\%). The least preferred strategy indicated by the lowest score is the Accommodating style (2\%). While the most preferred leadership style among the respondents is the Participative style (62\%). On the other hand, the Authoritarian style is the least preferred.

As cited by Caploy (2017), researchers have suggested that an individual's conflict style is a behavioral orientation of how to approach and handle conflict, with individuals choosing a pattern of 5 principles to guide them through the conflict process. These patterns evolve into actions and reactions that become known as their "style". Conflict management style is a "general and consistent orientation toward the other party and the conflict issues, manifest in observable behaviors that form a pattern and share common characteristics over time". Conflict management is presumed as a principle item in industrial organization behaviors and has an effective role in the amount of managers' performance and organization's outcomes. Furthermore, managers try to provide better conditions for obtaining tactful operation and convenient relations at an organization. Conflict drives from any abnormal behaviors between manager and staff that conduct their relationships in the work environment. Conflict is defined as a battle between managers and staff with various aims, attitudes, and needs (Rocafort, 2017). As cited by Agba and Ada (2015), conflict has been observed as an everyday phenomenon in private and working spheres of human activity. In modern times conflict when managed properly and carefully can become the most important tool in the development of the organization. Conversely, conflict is a part of organizational life and may occur within the individual, between individuals, between individuals and groups, and between groups. Conflict can be managed in different ways, some focusing on interpersonal relationships and others on structural changes.

\subsection{Foreign}

Research indicates that high-performance employees know how to manage conflict so that conflict makes a positive contribution, while less effective employees avoid conflict or allow it to produce negative consequences that in turn produce poor work performance (Desivilya, Somech, \& Lidgoster, 2010; Lester, Parnell, \& Carraher, 2010; Zhang, Cao, \& Tjosvold, 2011).

Southworth (2009) identified leadership as learning-centered leadership. He thought school leadership is (and must be) primarily about teaching and learning and asserted that leadership becomes "more potent when it focuses on developing students' learning and strengthening teaching". Knowing that learning is constructive, instructional leaders can emphasize the importance of talking about teaching and learning and engage in dialogue as learners. This dialogue brings to the forefront assumptions about teaching and learning and forces the teacher to come to terms with successes and challenges. Instructional leadership requires that leaders understand teaching, learning, and assessment within their schools and that their leadership entails the strategies to effect improvement. There are several criticisms of the instructional leadership model. One is that it is hierarchical. There is a top-down relationship between the principal and the teachers, as the principal takes on the role of curriculum expert and supervisor of curriculum and instruction (Goddard, 2003). A second criticism is that even if a principal is engaged in instructional leadership, one principal could not be capable of being a curriculum expert in all areas. Thirdly, because of the fragmented role of the principal, a principal would not have the time to effectively engage in instructional leadership without committing significant time off the clock (Hallinger, 2013). For these simple reasons, among others, the concepts of distributed and transformational leadership have evolved (del Castillo, 2021).

Kurtzberg (2015) brings forward that research has proved that there are three main types of conflicts. 
Conflicts are based on the work process, how work is performed, and the obligation of team roles and responsibilities. The second form of conflict is the relationship-based conflict, where relationships and interaction between team members are the sources. Finally, the third form is the task-based conflict where disagreements about the work task itself cause the issue. Moreover, he expresses that process-based and relationship-based conflicts only can have negative effects on team performance. The positive contribution through task-based conflicts is according to Kurtzberg et al. (2015) the promotion and unveiling of different perspectives which could stimulate innovation and creative thinking. The possible negative effects of a conflict are thus always a threat, according to Kurtzberg et al. (2015) psychological effects and team member relationships are at all times very vulnerable. They argue that it is tremendously difficult for individuals to remain objective about a situation when they feel that others are disagreeing, or even disapproving, of their point of view".

Somech (2009) brings forward studies that show that task interdependence demands team members to collaborate, followed by that high task interdependence implies the need for intense interactions among members, creating more opportunities for conflict". He expresses that competitive styles are most common in the early stages of team development and when there is a competition for project resources. This theory can be closely related to the definition of a high-performance team brought forward by Boddy (2002) where members of a high-performance team are deeply committed to one another's personal growth and a common purpose.

The related literature and studies reviewed by the researcher showed that there is no duplication of the studies which had already been conducted to the present study. However, they are similar in the aspects that this present study would like to find out the administrative competence and leadership styles of elementary School Heads in the Area 3 Division of Batangas.

\section{Research and methodology}

This segment of the study covers the research method used, respondents of the study, an instrument to be utilized, validity and reliability of the questionnaires, data gathering procedures, and the statistical treatment of the gathered data.

\subsection{Research design}

This study will use the descriptive research design since it tried to explain the current perceptions of the respondents on the perceptions of the school principals on home school relationships. According to Shields \& Rangarjan (2013), descriptive research is used to describe characteristics of a population or phenomenon being studied. It does not answer questions about when, how, and why the characteristics occurred. Rather it addresses the "what question" as to the characteristics of the population or situation being studied.

\subsection{Data gathering tool and procedure}

The nature of the study is descriptive. The study used an adopted questionnaire as the primary data gathering tool. It was adapted from Reginald (Reg) Adkins, Ph. Elemental Truths (IREM), and the 2007 board of regents of the University System of Georgia (developed by its GLISI, Georgia's Leadership Institute for School Improvement). The first part of the questionnaire consisted of the profile of the respondents in terms of age, gender, civil status, highest degree attainment, position, and years of teaching experience. It was followed by the leadership styles. The last part of the questionnaire is on administrative competence. A letter of request will be forwarded by the researcher to solicit the permission of the Division Schools Superintendent to administer the questionnaires to the target respondents. When the permission is granted, the researcher will then forward the questionnaire to the school heads of the public schools in Area 3, Division of Batangas. The researcher will spend a week surveying the respondents. The data will be collated, tallied, and statistically treated in two to three weeks.

84 Consortia Academia Publishing (A partner of Network of Professional Researchers and Educators) 


\subsection{Statistical treatment of data}

Frequency and Percentage. These are descriptive statistical tools that will be used to characterize the number of responses and its percentage of observations that exist for each data point or grouping of data points. In this study, the profile of the principals and master teachers will be presented using frequency and percentage.

Weighted Mean. This refers to the summation of the frequency of the responses of each weight multiplied by the numerical value of each weight divided by the total number of the respondents or cases. It will be used to describe the answers of the principals, heads, and master teachers based on their perception of their roles and practices on instructional supervision and their leadership style.

$$
\begin{array}{lll}
3.01-4.00 & - & \text { Strongly Agree } \\
2.01-3.00 & - & \text { Agree } \\
1.01-2.00 & - & \text { Disagree } \\
0.01-1.00 & - & \text { Strongly Disagree }
\end{array}
$$

Pearson $\boldsymbol{R}$ will be used to determine the relationship of the leadership style and their perception of the roles and practices given regarding instructional supervision.

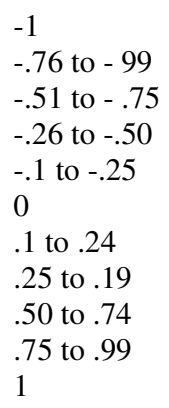

Perfect negative correlation
Very high negative correlation
High negative correlation
Moderately small negative correlation
Very small negative correlation
No correlation
Very small positive correlation
Moderately small positive correlation
High positive correlation
Very high positive correlation
Perfect positive correlation

\section{Presentation, interpretation and analysis of data}

This chapter presents the findings of the study which are interpreted and analyzed using appropriate statistical tools.

\subsection{Profile of the respondents}

\section{Table 1.1}

Age of the respondents

\begin{tabular}{rcc}
\hline Age & Frequency & Percentage \\
\hline $31-35$ years old & 1 & 1 \\
$36-40$ years old & 23 & 23 \\
$41-45$ years old & 19 & 19 \\
46 and above & 57 & 57 \\
\hline
\end{tabular}

Table 1.1 shows that a larger percentage of the respondents (57\%) have ages 46 and above while $23 \%$ of them have ages between 36 to 40 years old. This goes to show that the majority of the respondents are in adulthood (WHO, 2003).

\section{Table 1.2}

Gender of the respondents

\begin{tabular}{lcc}
\hline Sex & Frequency & Percentage \\
\hline Male & 15 & 22.4 \\
Female & 52 & 77.6 \\
\hline Total & 67 & 100 \\
\hline
\end{tabular}


Dimaculangan, D.

Out of 67 respondents, fifty-two are females (77.6\%) while the remaining are males $(22.4 \%)$. This conforms to the general trend that the teaching profession is dominated by females. Table 1.3 below shows the distribution of the respondents in terms of administrative positions in their respective schools.

Table 1.3

Position of the respondents

\begin{tabular}{|c|c|c|}
\hline Position & Frequency & Percentage \\
\hline TIC/OIC & 2 & 2 \\
\hline Head Teacher 1 and 2 & 20 & 20 \\
\hline Head Teacher 3 & 5 & 5 \\
\hline Principal 1 and 2 & 61 & 61 \\
\hline Principal 3 and 4 & 12 & 12 \\
\hline & 67 & 100 \\
\hline
\end{tabular}

The majority of the respondents are principals I and II (61\%). Twenty out of 100 school heads are head teachers I and II (20\%). The remaining are principal III and IV, head teacher III and TIC.

Table 1.4

Respondents' number of years as school head

\begin{tabular}{|c|c|c|}
\hline Number of years & Frequency & Percentage \\
\hline 30 years above & 14 & 20.9 \\
\hline $20-29$ years & 33 & 49.3 \\
\hline $10-19$ years & 17 & 25.4 \\
\hline $5-9$ years & 2 & 3.0 \\
\hline 5 years below & 1 & 1.5 \\
\hline Total & 67 & 100 \\
\hline
\end{tabular}

Table 1.4 presents the distribution of the respondents based on the number of their teaching experiences. The greatest number of respondents $(49.3 \%)$ have between 20 to 29 years of teaching experience. On the other hand, only one school head $(1.5 \%)$ has teaching experience of five years below. These demographics point to the fact that the majority of the respondents have been in the teaching profession for quite a long time since they are now holding key leadership positions in their respective schools.

\subsection{Leadership styles of the school heads}

Table 2 below shows the distribution of the preferred leadership styles of the head teacher respondents.

Table 2

Leadership styles of the school heads

\begin{tabular}{|c|c|c|}
\hline Leadership Style & Frequency & Percentage \\
\hline Authoritarian & 15 & 15 \\
\hline Participative & 72 & 72 \\
\hline Delegative & 13 & 13 \\
\hline Total & 67 & 100 \\
\hline
\end{tabular}

The table shows that the most preferred leadership style among the respondents is Participative Style (72\%). This connotes that the majority of the respondents perceive that they include one or more employees in the decision-making process, but they normally maintain the final decision-making authority.

According to Saeed et al. (2014), a participative leader, rather than taking autocratic decisions, seeks to involve other people in the process, possibly including subordinates, peers, superiors, and other stakeholders. Often, however, as it is within the managers' whim to give or deny control to his or her subordinates, most participative activity is within the immediate team. On the other hand, the Delegative style is the least preferred leadership style (13.4)

86 Consortia Academia Publishing (A partner of Network of Professional Researchers and Educators) 
Leadership styles and roles on instructional supervision of the school heads of area 3 division of Batangas

\subsection{Perceived roles in instructional supervision}

Table 3.1 below shows the administrative competence of the school heads in terms of instructional development.

Table 3.1

Perceived roles in instructional development

\begin{tabular}{lcc}
\hline \multicolumn{1}{c}{ Instructional Development } & Mean & Rank \\
\hline $\begin{array}{l}\text { Enables teachers to develop competencies in lesson planning. } \\
\text { Helps teachers to set up simple experimental classrooms and evaluation } \\
\text { for improvement. }\end{array}$ & 4.61 & 6 \\
$\begin{array}{l}\text { Helps teachers develop skills of applying different assessment and } \\
\text { measurement techniques through organizing in-service training. }\end{array}$ & 4.45 & 5 \\
$\begin{array}{l}\text { Helps teachers in the selection of appropriate resources like teaching aids. } \\
\begin{array}{l}\text { Provides immediate feedback to teachers particularly after lesson } \\
\text { observation. }\end{array}\end{array}$ \\
$\begin{array}{l}\text { Helps to organize meetings for teachers to solve common instructional } \\
\text { problems. }\end{array}$ & 4.52 & 4 \\
\hline \multicolumn{1}{c}{ Composite Mean } & 4.58 & 3 \\
\hline
\end{tabular}

Based on the composite mean of 4.54, it connotes that the respondents claim that the role of school heads in instructional development is very high. The indicator that was rated the highest (4.61) is the one that states that they enable teachers to develop competencies in lesson planning. This is followed by the indicator that says they provide immediate feedback to teachers particularly after lesson observation (4.60).

Table 3.2

Perceived roles in curriculum development

\begin{tabular}{lcc}
\hline \multicolumn{1}{c}{ Curriculum Development } & Mean & Rank \\
\hline Assists in the implementation of the curriculum. & 4.57 & 2 \\
Helps to evaluate the existing curriculum so as to take immediate corrective measure & 4.30 & 6 \\
Helps to identify students and community needs so as to improve the curriculum. & 4.60 & 1 \\
Helps to identify the problems in implementing the existing as per the education policy. & 4.45 & 4.5 \\
Helps to introduce new technology tools for teachers that are suitable for curriculum & 4.45 & 4.5 \\
Helps to collect and provide necessary educational materials that are supportive to the & 4.54 & 3 \\
& & \\
\hline
\end{tabular}
curriculum.

Composite Mean $\quad 4.48$

Table 3.2 below shows the administrative competence of the school heads in terms of curriculum development. Based on the composite mean of 4.48, it connotes that the respondents claim that the perceived roles of school heads in terms of curriculum development are high. The indicator that was rated the highest (4.60) is the one that states that they help to identify students and community need to improve the curriculum. This is followed by the indicator that says they assist teachers in the implementation of the new curriculum (4.57).

Table 3.3

Perceived roles in staff development

\begin{tabular}{lcc}
\multicolumn{1}{c}{ Staff Development } & Mean & Rank \\
\hline Contribute to enhance professional competence of teachers & 4.43 & 6 \\
Helps teachers to share best practices from schools & 4.61 & 2 \\
Enhance teachers' continuous professional dev't. & 4.54 & 3 \\
Facilitate mentoring for newly assigned teachers. & 4.45 & 4.5 \\
Ensure the delivery of effective staff development & 4.45 & 4.5 \\
Gives feedback to teachers. & 4.62 & 1 \\
\hline & Composite Mean & \multicolumn{2}{c}{4.52} \\
\hline
\end{tabular}

Table 3.3 shows the perceived roles of school heads in terms of staff development. Based on the composite 
Dimaculangan, D.

mean of 4.52, it connotes that the respondents claim that the perceived roles of school heads in terms of staff development are high. The indicator that was rated the highest (4.62) is the one that states that they give feedback to teachers. This is followed by the indicator that says they help teachers to share best practices from different schools (4.61).

Table 3.4

Perceived roles in learners' development

\begin{tabular}{lcc}
\hline \multicolumn{1}{c}{ Staff Development } & Mean & Rank \\
\hline Improve learners' interpersonal skills & 4.61 & 2 \\
Increase learners' motivation & 4.54 & 3 \\
Develop camaraderie among learners & 4.45 & 4 \\
Develop learners' multiple intelligences & 4.40 & 5 \\
Improve learners' achievement & & 4.62 \\
\hline
\end{tabular}

Table 3.4 shows the perceived roles of school heads in terms of learners' development. Based on the composite mean of 4.52, it connotes that the respondents claim that the perceived roles of school heads in terms of learners' development are high. The indicator that was rated the highest (4.62) is the one that states that they improve learners' achievement. This is followed by the indicator that says they help improve learners' interpersonal skills (4.61)

\subsection{Association of profile variables and leadership styles of the school heads}

Table 4 below shows the level of association between the profile of the respondents and their Leadership Styles. The table above shows the association between the profiles of the respondents and their leadership styles. Statistical tests showed that there is a significant relationship between the preferred leadership styles of the respondents and their profile variables at 0.05 level of significance. This finding is parallel to the claim of Barki and Hartwick (2011) that preferred leadership styles do not vary much among persons of similar status and age ranges.

Table 4

Association of profile variables and leadership styles

\begin{tabular}{|c|c|c|c|}
\hline PROFILE & Chi-square value & p-value & Interpretation \\
\hline Age & 17.560 & 0.007 & Significant \\
\hline Gender & 6.691 & 0.035 & Significant \\
\hline Position & 15.007 & 0.020 & Significant \\
\hline Number of years as school head & 19.93 & 0.013 & Significant \\
\hline
\end{tabular}

\subsection{Association of profile variables and perceived roles in instructional supervision}

Table 5 below shows the level of association between the profile of the respondents and their perceived roles as instructional supervision. The statistical test showed that there is no significant relationship with perceived roles in instructional supervision of the respondents when grouped according to age, gender, position, and the number of years as school head ( $p>0.05$ ). This finding supports the claim of Abwalla (2014) that administrative competence does not vary much among persons of similar status and age ranges.

\section{Table 5}

Association of profile variables and perceived roles on instructional supervision

\begin{tabular}{|c|c|c|c|}
\hline PROFILE & Chi-square value & p-value & Interpretation \\
\hline Age & 14.286 & 0.577 & Not Significant \\
\hline Gender & 9.813 & 0.430 & Not Significant \\
\hline Position & 25.795 & 0.057 & Not Significant \\
\hline Number of years as school head & 23.250 & 0.107 & Not Significant \\
\hline
\end{tabular}

88 Consortia Academia Publishing (A partner of Network of Professional Researchers and Educators) 
Leadership styles and roles on instructional supervision of the school heads of area 3 division of Batangas

4.6 Relationship between leadership styles and perceived roles for instructional supervision

Table 6 below shows the level of relationship between the preferred leadership styles and the perceived roles of school heads in instructional supervision. The table shows that based on the result of the statistical test, there is no significant correlation between the school heads' leadership styles and perceived roles in instructional supervision based on the p-value that is greater than 0.05 .

Table 6

Relationship between leadership style and instructional supervision

\begin{tabular}{lcccccc}
\hline \multicolumn{1}{c}{ Variables } & Mean & SD & r value & p-value & $\begin{array}{c}\text { Verbal } \\
\text { Interpretation }\end{array}$ & Decision \\
\hline Leadership Style & 1.99 & 0.54 & & & & \\
Instructional & 4.52 & 0.08 & 1.00 & 0.146 & Not Significant & Accept Ho \\
Supervision & & & & & & \\
\hline
\end{tabular}

This finding is in agreement with the reports of Dartling et al. (2007) that regardless of the leadership style a school head possesses, his administrative competence may be high or low. Many view leadership, management, and administration as synonymous, but there are primary differences. It is not unusual for firms to expect individuals to possess the skills required for each. However, an individual's unique abilities will determine whether they enjoy the responsibilities and are successful.

\section{Summary, conclusion and recommendation}

This chapter presents the summary of the study conducted as well as the recommendations borne out of the findings of the study.

\subsection{Summary}

Instructional leadership is learning-focused, learning for both students and adults, and learning is measure by improvement in instruction and the quality of student learning. Instructional leadership must reside with a team of leaders of which the principal serves as the leader of leaders. Utilizing quantitative descriptive research design, the study was conducted to find out the preferred leadership styles and perceived role on instructional supervision of School Heads of selected schools from Area 3 Division of Batangas and thereby provide input to the management program.

\subsection{Findings}

Profile of the respondents - A larger percentage of the respondents (57\%) have ages 46 and above while $23 \%$ of them have ages between 36 to 40 years old. This goes to show that the majority of the respondents are in adulthood (WHO, 2003). Out of 67 respondents, fifty-two are females (77.6\%) while the remaining are males $(22.4 \%)$. This conforms to the general trend that the teaching profession is dominated by females. The majority of the respondents are principals I and II $(61 \%)$. Twenty out of 100 school heads are head teachers I and II (20 $\%)$. The remaining respondents are principals III and IV, head teacher III and TIC. The greatest number of respondents (49.3\%) have between 20 to 29 years of teaching experience. On the other hand, only one school head $(1.5 \%)$ has teaching experience of five years below. These demographics point to fact that the majority of the respondents have been in the teaching profession for quite a long time since they are now holding key leadership positions in their respective schools.

Leadership Styles of the School Heads - The most preferred leadership style among the respondents is the Participative Style (72\%). This connotes that the majority of the respondents perceive that they include one or more employees in the decision-making process, but they normally maintain the final decision-making authority. 
Perceived Roles in Instructional Supervision - The respondents claim that the role of school heads in instructional development is very high. The indicator that was rated the highest (4.61) is the one that states that they enable teachers to develop competencies in lesson planning. This is followed by the indicator that says they provide immediate feedback to teachers particularly after lesson observation (4.60). Based on the composite mean of 4.48 , it connotes that the respondents claim that the perceived roles of school heads in terms of curriculum development are high. The indicator that was rated the highest (4.60) is the one that states that they help to identify students and community need to improve the curriculum. This is followed by the indicator that says they assist teachers in the implementation of the new curriculum (4.57). Based on the composite mean of 4.52 , it connotes that the respondents claim that the perceived roles of school heads in terms of staff development are high. The indicator that was rated the highest (4.62) is the one that states that they give feedback to teachers. This is followed by the indicator that says they help teachers to share best practices from different schools (4.61). Based on the composite mean of 4.52, it connotes that the respondents claim that the perceived roles of school heads in terms of learners' development are high. The indicator that was rated the highest (4.62) is the one that states that they improve learners' achievement. This is followed by the indicator that says they help improve learners' interpersonal skills (4.61).

Association of Profile Variables and Leadership Styles of the School Heads - The statistical test showed that there is a significant relationship between the preferred leadership styles of the respondents and their profile variables at a 0.05 level of significance.

Association of Profile Variables and Perceived Roles in Instructional Supervision - Statistical tests showed that there is no significant relationship in the administrative competence of the respondents when grouped according to age, gender, position, and the number of years as school head ( $p>0.05)$.

Relationship between Leadership Styles and Perceived Roles for Instructional Supervision - Based on the result of the statistical test, there is no significant correlation between the school heads' leadership styles and administrative competence based on the p-value that is greater than 0.05 .

\subsection{Conclusions}

Based on the foregoing findings, the following conclusions were drawn:

$>$ Majority of the respondents are ages 46 and above, female school principals who have between 20 to 29 years of teaching experience.

$>$ The most preferred leadership style among the respondents is Participative Style

$>$ The respondents claim that the role of school heads in instructional development is very high.

$>$ There is a significant relationship between the preferred leadership styles of the respondents and their profile variables

$>$ Statistical test showed that there is no significant relationship with perceived roles in instructional supervision

$>$ There is no significant correlation between the school heads' leadership styles and perceived roles in instructional supervision.

\subsection{Recommendations}

Based on the foregoing findings and conclusions of the study, and to affect effective leadership and sound administrative competence, the researcher puts forward the following:

$>$ School heads should, through planned exercises, be able to negotiate and analyze strategies and tactics

90 Consortia Academia Publishing (A partner of Network of Professional Researchers and Educators) 
Leadership styles and roles on instructional supervision of the school heads of area 3 division of Batangas

for effectively implementing their available power in administration and leadership.

$>\quad$ Skill and comfort in using a variety of conflict-handling modes may help to develop a repertoire of conflict resolution skills that is essential in effectively managing a variety of situations.

$>\quad$ School heads must serve as role models. Role modeling can be an effective teaching and learning strategy, providing managers have the skills and abilities required.

$>\quad$ School heads should possess skills desired in enacting the facilitation role including counseling, cross-cultural communication, human relations, and giving and receiving feedback on behavior.

$>\quad$ Further research on individual and environmental characteristics could contribute significantly to our understanding of leadership styles and administrative competence. Other variables rather than leadership style and administrative competence may influence the success of a school head. More research is necessary on the effects of personality and characteristics of the organizational environment.

\section{References}

Abwalla, J. (2014). The principals' leadership styles and teachers' performance in general secondary schools of Gambella regional state Approach. Needham Heights: Allyn \& Bacon.

Aritzeta, A., Ayestaran, S., \& Swailes, S. (2015). Team role preference and administrative competence. The International Journal of Conflict Management, 16(2), 157-182. https://doi.org/10.1108/eb022927

Aula, P., \& Siira, K. (2010). Organizational communication and conflict management systems. Nordicom Review 31(1), 125-141. https://doi.org/10.1515/nor-2017-0125

Badler, H. (2018). Administrative competence in the workplace.

Brett, J. M. (2017). Negotiating globally: How to negotiate deals, resolve disputes, and make decisions. San Francisco: Jossey-Bass.

Brown, S. T. (2012). Conflict management in projects. Global Knowledge Course.

Burns, A. C., \& Bush, R. F. (2009). Marketing research. New Jersey: Prentice Hall.

Darling, J., \& Walker, W. (2017). Effective management: Use of the behavioral style model. Leadership and Organization Development Journal, 22(5). https://doi.org/10.1108/01437730110396375

del Castillo, F. (2021). Leadership: Towards equitable COVID-19 vaccination. Journal of Public Health, 43(2), 346-347. https://doi.org/10.1093/pubmed/fdab051

Desivilya, H. S., \& Eizen, D. (2015). Conflict management in work teams: The role of social self-efficacy and group identification. The International Journal of Conflict Management, 16(2), 183-208. https://doi.org/10.1108/eb022928

Desivilya, H. S., \& Yagil, D. (2015). The role of emotions in conflict management: The case of work teams. The International Journal of Conflict Management, 16(1), 55-69. https://doi.org/10.1108/eb022923

Deutch, M., \& Coleman, P. T. (2016). The handbook of administration. San Francisco: Jossey Bass. 
Dimaculangan, D.

92 Consortia Academia Publishing (A partner of Network of Professional Researchers and Educators) 